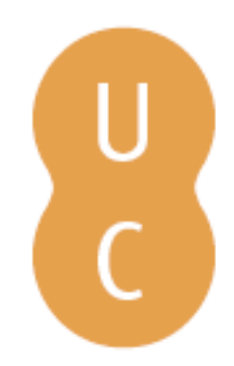

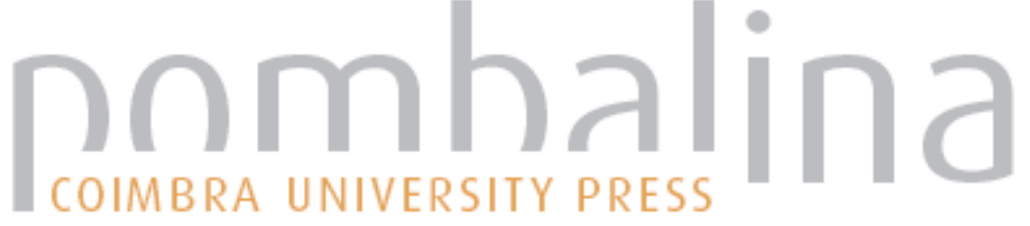

\section{Vasco da Gama entre Poggio Bracciolini e Camões}

\author{
Autor(es): $\quad$ Moura, Vasco Graça \\ Publicado por: Imprensa da Universidade de Coimbra \\ URL \\ persistente: URI:http://hdl.handle.net/10316.2/31253 \\ DOI: $\quad$ DOI:http://dx.doi.org/10.14195/978-989-26-0569-2_40 \\ Accessed : $\quad$ 26-Apr-2023 12:17:17
}

A navegação consulta e descarregamento dos títulos inseridos nas Bibliotecas Digitais UC Digitalis, UC Pombalina e UC Impactum, pressupõem a aceitação plena e sem reservas dos Termos e Condições de Uso destas Bibliotecas Digitais, disponíveis em https://digitalis.uc.pt/pt-pt/termos.

Conforme exposto nos referidos Termos e Condições de Uso, o descarregamento de títulos de acesso restrito requer uma licença válida de autorização devendo o utilizador aceder ao(s) documento(s) a partir de um endereço de IP da instituição detentora da supramencionada licença.

Ao utilizador é apenas permitido o descarregamento para uso pessoal, pelo que o emprego do(s) título(s) descarregado(s) para outro fim, designadamente comercial, carece de autorização do respetivo autor ou editor da obra.

Na medida em que todas as obras da UC Digitalis se encontram protegidas pelo Código do Direito de Autor e Direitos Conexos e demais legislação aplicável, toda a cópia, parcial ou total, deste documento, nos casos em que é legalmente admitida, deverá conter ou fazer-se acompanhar por este aviso.

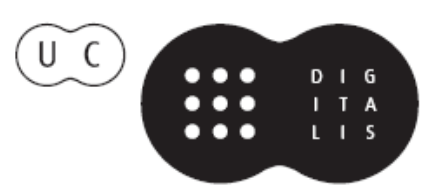




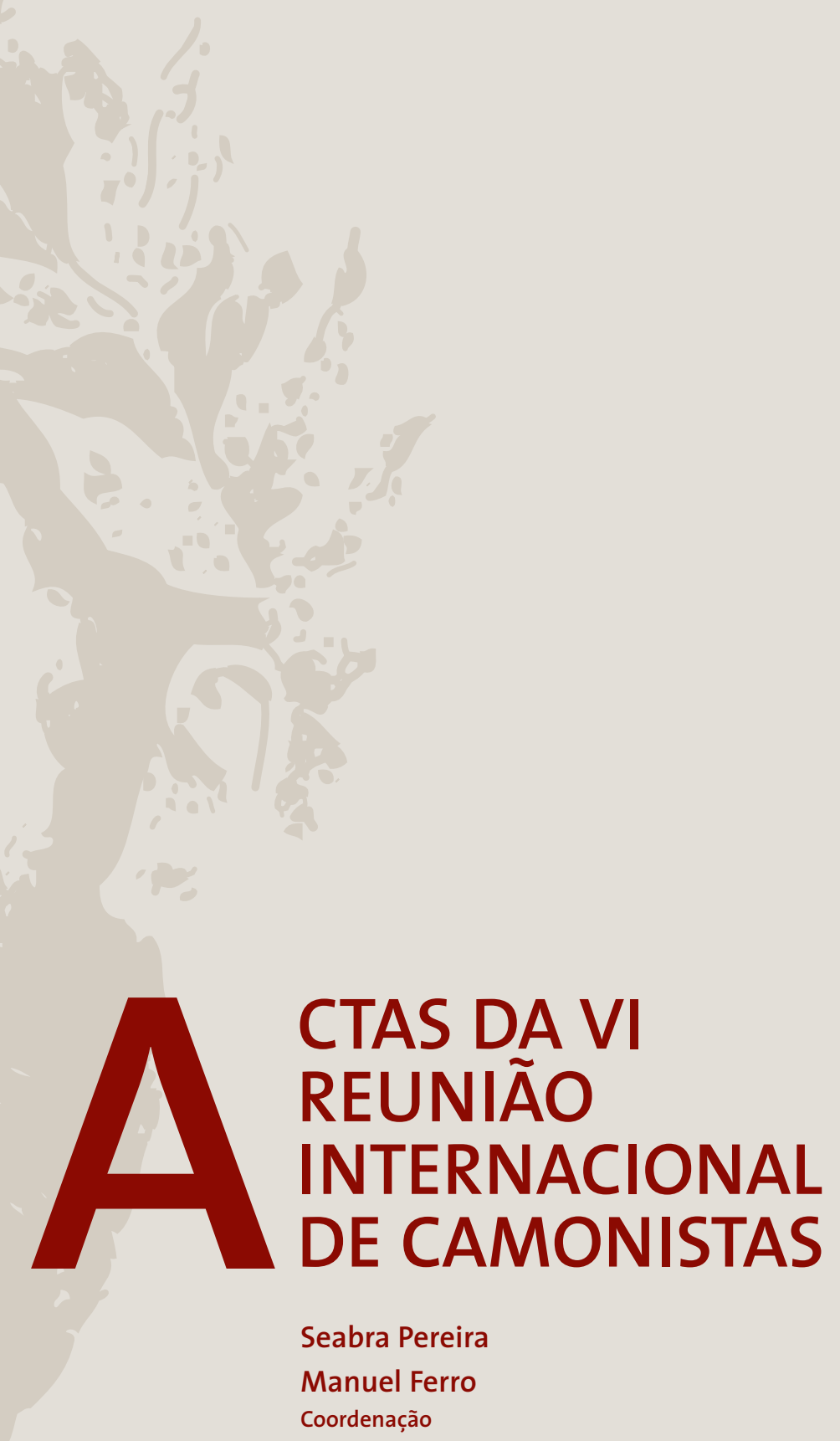




\section{VASCO DA GAMA ENTRE POGGIO BRACCIOLINI E CAMÓES}

1. A historiografia dos Descobrimentos de há muito que admite uma hipótese extremamente plausível, segundo a qual, no período de cerca de nove anos que vai do regresso de Bartolomeu Dias à partida do Gama, o Atlântico Sul terá sido sistematicamente explorado, a fim de se obter um conhecimento seguro do regime de ventos e correntes, bem como de outros aspectos ligados à navegação oceânica que pudessem interessar à travessia ${ }^{1}$. Sem essa exploração prévia, realizada muito provavelmente por caravelas, as naus, mais pesadas e de mais difícil manobra, não teriam podido aventurar-se a tal cometimento. Talvez daí também tivesse advindo um conjunto de informaçôes mais concretas que tornaram possível o descobrimento oficial do Brasil em 1500, por uma armada que se dirigia à Índia, a de Cabral.

Isto quer dizer também que Vasco da Gama se insere "organicamente" não apenas no processo, quantas vezes anónimo, dos descobrimentos atlânticos, mas ainda numa sequência de viagens que foram preparatórias da sua, tendo esta sido a resultante daquelas. E portanto, independentemente do expediente que, usando-o como protagonista, veio a convertê-lo no singular herói épico de Os Lusíadas, em cuja progressão lhe cabe representar toda a nação portuguesa e a sua história, pode dizer-se que sempre haveria uma outra boa razão concreta para esse protagonismo: Vasco da Gama rematava e coroava uma série de esforços colectivos realizados com vista à preparação da sua própria viagem.

2. Todavia, a matéria dos descobrimentos, com toda a sua revolucionária importância, reportava-se a situaçóes que escassamente se adequariam a um propósito épico de matriz clássica. Nostálgicos desta, os humanistas propunham-se utilizá-la. Mas é evidente que teriam de se sentir encaminhados para a história pois, se algum tivesse tentado a epopeia, não poderia ser bem sucedido, sendo de supor que se sentiria demasiado amarrado às convençôes do género. Longos e morosos períodos de vida no mar, sem terra à vista nem acontecimentos relevantes; complexas questôes técnicas de navegação, de orientação astronómica e de utilização de instrumentos; calmarias, tempestades e dificuldades de

\footnotetext{
${ }^{1}$ Armando Cortesão, O mistério de Vasco da Gama, Coimbra, Junta de Investigações do Ultramar, 1973, p. 168 e n. 12.
} 
toda a ordem a bordo; situaçôes de trato mercantil corrente ou de violência perpetrada contra Africanos, que a mentalidade da época conceberia fundamentalmente como seres escravizáveis e objecto de comércio, e portanto sem a dignidade de adversários cujo valor estivesse à altura de um protagonista de epopeia - tudo isto tornava impraticável, em princípio, isolar uma figura grandiosa e digna de ser cantada, de entre os "rudos" marinheiros e seus não menos "rudos" capitães. Afigurar-se-ia pois impossível, na prática, caracterizar como épicos os feitos respectivos.

Dissipados os medos, conhecida a realidade, havida notícia de factos e de incidentes, tudo relevava, pela sua própria imediação, muito mais para o conhecimento empírico das novidades do mundo e sua descrição em prosa do que para a alta criação poéticoliterária. As peripécias que fossem conhecidas dificilmente se ajustariam assim, no plano da escrita, àquela dimensão sobre-humana do herói que se move num universo povoado de mitos e era essa dimensão sobre-humana que os humanistas não podiam deixar de ver figurada nas epopeias clássicas. Depois, mal se compreenderia que se cantasse uma geografia fantástica exactamente quando a da terra deixava de o ser e quando, como refere Magalhães Godinho, o espaço começa a ser construído, já não "em função de símbolos ou mitos", mas em termos de operatória física, e representado "mentalmente com a eficácia de orientar a acção» ${ }^{2}$; como mal se compreenderia que se engendrassem peripécias com intervenção de seres fabulosos numa época em que os descobrimentos demonstravam a sua própria inexistência.

3. Não pode dizer-se todavia que, com os descobrimentos, a propensão para a deriva pelo fantástico e para a estruturação dos mitos tenha desaparecido completamente. As construçôes respeitantes ao El Dorado e à localização do Paraíso terrestre, elaboradas por círculos colombinos, ou a inclusão de seres fabulosos e de monstros em gravuras da época, e mesmo as suas descriçóes em relatos de viagens, documentam a permanência destas representaçóes no imaginário europeu. Só que o El Dorado e o Paraíso terrestre não seriam propriamente idóneos para alimentar a imaginação épica de inspiração clássica - até porque a Idade de Ouro era por definição anterior aos conflitos entre os homens e à luta destes contra a adversidade -, e as fantasias zoomórficas passaram a valer como registo de curiosidades ou singularidades da Natureza, sem força sugestiva para neutralizar a recente e radical alteração das concepçôes antropológicas, em vias de assentarem na fundamental unidade da espécie humana à escala do planeta ${ }^{3}$. Rapidamente, aliás, e sobretudo a partir da penetração espanhola nas Américas, dessas concepçóes derivaram as construçóes de direito natural e de direito das gentes que, postulando a igualdade ontológica e a dignidade de todos os seres humanos, delas concluíam a correlativa igualdade de direitos, teorizavam sobre a guerra justa e desenvolviam uma crítica sistemática dos feitos de conquista e das atrocidades perpetradas contra nativos ${ }^{4}$,

2 Vitorino Magalhães Godinho, Mito e mercadoria, utopia e prática de navegar, séculos XIII-XVIII, Lisboa, Difel, 1990, pp. 78-79. E também "Os Descobrimentos: inovação e mudança nos séculos XV e XVI”, Revista de História Económica e Social, no 2, 1978, pp. 1-27.

3 José Sebastiāo da Silva Dias, Os Descobrimentos e a problemática cultural do século XVI, Coimbra, Faculdade de Letras, 1973, pp. 197-203.

${ }^{4}$ Para uma boa síntese destes problemas e do quadro polémico em que surgiram, cfr. Anthony Pagden, La caída del hombre natural (trad. esp.), Madrid, Alianza Editorial, 1988. 
o que, a seu modo, teria também contribuído para desmotivar as veleidades heróicas, no próprio berço do Humanismo, onde desde cedo se ergueram vozes fortemente acusadoras da leyenda negra ${ }^{5}$.

O mito entra assim num compasso de espera, até que novas condições lhe permitam reviver, mas tornando-se naquilo que naturalmente já tendia a ser em absoluto, desde que o Cristianismo se substituíra ao Paganismo: uma simples alegoria que se admitia coexistisse com ele, ou ficção desmontável após a feitura dos "versos deleitosos" para que servira, como se vê em Camóes (Lus., X, 82). Esse esvaziamento total das figuraçóes, após uma sua encenação à maneira do mito, é já tipicamente maneirista. No episódio do Adamastor, por exemplo, temos, ao mesmo tempo, uma situação clássica de metamorfose e um processo maneirista de auto-retrato deformado e projectado naquela. Como mito posto em cena num momento crucial do percurso, o Adamastor náo é apenas um episódio central no "espaço" do poema ${ }^{6}$. É-o como primeiro dispositivo de encaixe da pessoa do autor e da ressonância das desgraças por que passou, amplificadas na sua própria narração épica. É-o também na trajectória da viagem e no preciso vértice do espaço geográfico através do qual ela se produz, transfigurando os limites de um espaço inultrapassável ou proibido, os «vedados términos» (Lus., V, 41).

4. Voltando à questão das viagens, ocorria pois um relativo anonimato dos protagonistas de uma progressão marítima que não ia fazendo retumbar façanhas esplendorosas, dessas que seriam idóneas para alimentarem um epos nacional. Adiante-se que é também notória a "pobreza" da viagem de Vasco da Gama a tal respeito. Sem contar que, no plano guerreiro das expediçóes norte-africanas, cuja localização geográfica acarretava inevitavelmente uma aproximação com a Cartago da Eneida, pesariam mais os feitos e interesses aristocráticos, alguns sem dúvida cantáveis em termos de heroicidade, mas todos eles sem qualquer relevância visível para o que era efectivamente sentido como progresso revolucionário no conhecimento do mundo.

A focagem proposta pelos humanistas, entáo mais preocupados com o ideal ciceroniano do discurso do que com a escrita poética de grande fôlego, propenderia para a criação de monumentos de eloquência historiográfica compatíveis com a glória do rei e com a elegante revalorização do Latim clássico. Poliziano escreve a D. João II:

"Quero suplicar-te em nome não somente deste século, mas também de toda a posteridade, que náo consintas venha a perecer ou apagar-se a memória de táo grandes obras, que se deve guardar para a eternidade, mas ordenes se perpetue na voz férrea ou antes diamantina dos homens doutos, a qual nem a acção roedora do tempo no seu rodar silencioso chega jamais a consumir". ${ }^{7}$

Por outro lado, devemos perguntar-nos se a centralização do poder real, com a correlativa reivindicaçáo do exclusivo da coroa quanto ao monopólio das viagens

5 Cfr. Ricardo García Cárcel, La leyenda negra / Historia y opinión, Madrid, Alianza Editorial, 1992, pp. 233-244.

${ }^{6} \mathrm{O}$ episódio do Adamastor ocupa, no Canto V de Os Lusíadas, as estâncias 37 a 60 . Ou seja, aquelas a que correspondem os $n^{\circ}$ s de ordem 503 a 526 na totalidade das 1102 estâncias do poema.

${ }^{7}$ Cfr. Fidelino de Figueiredo, A épica portuguesa no século XVI, Lisboa, INCM, 1987, pp. 92-107. 
marítimas, não forçaria o ritualismo literário da época a encabeçar no soberano a realização das proezas individuais supostamente cantáveis, quando, afinal, era sabido que o rei náo as tinha praticado em pessoa, tornando-se muito mais complicado endossar-lhas nesses termos, salvo como pura generalidade. O que muito provavelmente dificultava as coisas, ou levava mesmo a que a ideia nem sequer ocorresse aos candidatos à adjudicação de tais incumbências. Enfim, passando para o plano da língua portuguesa, ela não se encontrava retoricamente ainda apetrechada para a produção de uma epopeia, o que só conseguirá resolver quando uma evolução retórica e prosódica lhe permite apropriar-se dos modelos do decassílabo heróico e dos moldes amplos da oitava italiana, deixando-a pronta para mais altos e concatenados voos narrativos.

5. Em cima dos acontecimentos, ficava, ipso facto, por resolver a contradição essencial que implicaria conciliar a efabulação mítica com a realidade tão recentemente e tão profundamente transtornada: a primeira nascera em conexáo com um espaço fechado, mediterrânico, imobilizado em termos de longue durée, com todas as sedimentaçóes culturais e antropológicas consequentes; a segunda surgia agora ligada a um espaço aberto e expansivo, em que "o desconhecido se desvanecia no conhecido» ${ }^{8}$, e a cuja atlanticidade, a princípio de configuração indeterminada, se sucedia o extravasamento para outras massas oceânicas e para novas realidades continentais que não cessavam de surpreender. A própria compatibilização entre as novas coordenadas de um continuum espacio-temporal ${ }^{9}$ assim bruscamente subvertido e uma concepção cósmica ainda hibridamente medievo-ptolomaica náo iria sem levantar os maiores problemas neste aspecto. $\mathrm{O}$ espaço e o tempo da epopeia clássica tinham nascido como decorrência das noçóes de espaço e tempo empiricamente aferidas dentro de parâmetros convencionais, localizados, restritos, próprios de um mundo encravado no Mediterrâneo ${ }^{10}$. Correspondem a funçóes simbólicas do mito que são indissociáveis dos modos de estruturar originariamente o mundo. Cassirer mostrou que a visão mítica parte de um círculo estreito da existência sensível e espacial que só muito lentamente se alarga ${ }^{11}$. E escreve também:

"A totalidade do mundo do espaço, e, com ele, do cosmos em geral, aparece construída segundo um certo modelo que pode apresentar-se-nos ora numa

\footnotetext{
${ }^{8}$ Magalhães Godinho, “Os Descobrimentos: inovação e mudança...”, p. 2.

9 "Não se mede e configura o espaço sem medir e configurar o tempo» (...) «Também o tempo fica imóvel ou decorre, é longo ou curto consoante as técnicas de movimento dos homens e a consciência da maneira como encaram as possibilidades ou não das ligaçóes entre presente e passado, presente e futuro, em especial o sentido da mudança e da inovaçāo» - Magalhães Godinho, op. cit., p. 3.

${ }^{10}$ Cfr. Victor Jabouille, O Mediterrâneo Antigo, unidade e diversidade, Lisboa, Ediçōes Colibri, 1996, p. 46. E também Joël Thomas, "Epopée et initiation. Le sens du voyage, et le 'tissage' de l'espace-temps du heros dans l'Enéide", in L'imaginaire de l'espace et du temps chez les Latins, Cahiers de l'Université de Perpignan, 1988, pp. 54-55: "(..) l'espace du voyage était fermé sur lui-même, mais ouvert sur un Centre. En ceci, il se distingue de l'espace 'moderne', celui des conquérants, celui qui, à partir de la Renaissance, s'ouvre sur la périphérie, l'inconnu, voire l'illimité. Ce la n'empêche nullement les Romains d'être des conquérants; mais leur relation à l'espace, au champ de leur action, reste subordonnée à une vision du monde symbolique, à une superstructure qui, pour eux, est l'espace véritable».

${ }^{11}$ Ernst Cassirer, La philosophie des formes symboliques (trad. fr.), Paris, Les éditions de minuit, 1972, II, p. 117.
} 
escala ampliada ora numa escala reduzida, mas que permanece sempre idêntica, no máximo como no mínimo. Toda a coerência no espaço mítico repousa em última análise nessa identidade originária; remonta, não a uma homogeneidade do agir, a uma lei dinâmica, mas a uma identidade originária da essência."12

É interessante concluir por essa presença concreta do universo mediterrânico na Ars Poetica de Marco Girolamo Vida, publicada em 1527, quando já pode considerar-se quase encerrado o ciclo das grandes navegaçôes. Sáo várias as referências a trajectos no espaço, percursos de jornada, viagens por mar, e reconhecimento da meta almejada pelo viajante, no contexto da criaçáo épica, mas elas culminam de um modo perfeita e mediterranicamente revelador para o que se vem dizendo:

"Por isso, quando já os navegantes se fizeram ao mar sulcando as salsas ondas com a quilha de bronze, podeis ver a sua superfície tranquila espumando, revolvida pelo impulso dos remos e pelos esporóes sonorosos. Ora, ao longe, ressoam os rochedos batidos pelo mar, ora o abismo começa a encrespar-se, agitado pelos ventos. Na praia rebentam as ondas com um som cavo, e o rebentar da vaga rumoreja de encontro aos recifes; segue-se imediatamente, talhada a pique, uma enorme massa de água. Logo de seguida poder-se-á ver à distância toda a Sicília estremecer nos seus alicerces e as altas montanhas a chocar umas com as outras"13 (itálicos meus).

Tratava-se portanto, ainda nesta preceptística tardia, de um espaço-tempo sem convulsóes, que abria para as regiôes do mito e das suas dimensóes imaginariamente vividas, como forma de simbolizar a história e as representações do mundo de um determinado grupo. Tudo isso era sentido agora em vias de ser profundamente abalado, pelo que seria difícil que um género entretanto altamente codificado pela teorização poética, como a epopeia literária, pudesse arrancar da própria instabilidade dessas coordenadas: não haveria condiçôes para um primordial reconhecimento ou estabelecimento da identidade do grupo cantado, enquanto tal, por parte do cantor, nem para a manipulaçáo de um espaço que lhe escapava de todo e para o qual não dispunha de analogias.

E talvez houvesse ainda uma outra dificuldade. Segundo Joël Thomas ${ }^{14}$, há uma relação estreita entre os percursos "diurnos" da epopeia clássica projectada na viagem heróica e a trajectória do sol de nascente para poente, estabelecendo-se a dos percursos em sentido inverso com a treva, o outro mundo, a demanda do lugar do Centro, da Origem e da Criação ${ }^{15}$. Como compatibilizar a viagem de Vasco da Gama com o

12 Id., ibid., p. 115.

13 Cito pela tradução de Arnaldo M. Espírito Santo, Arte Poética de Marco Girolamo Vida, Lisboa, INIC, 1990, III, vv. 385-394, p. 283 (cfr. pp. 173, 175, 195, 203, 221).

${ }^{14}$ Op. cit., pp. 37-43.

15 Cfr. Stephen Reckert, "A Ilha dos Amores; metáfora e metonímia”, in AA. VV., A viagem de 'Os Lusiadas': símbolo e mito, Lisboa, Arcádia, 1981, especialmente pp. 111-118. 
movimento do sol, nessa forma de escandir a jornada, poderia ser também uma séria dificuldade, mesmo que tal correlação fosse só subconscientemente pressentida.

Para Camões, culturalmente integrado num outro tipo de consciência "norte-sul" da expressão geográfica do mundo, e portanto em condições, já não classicamente determinadas, de contrapor outras direcçôes à trajectória do sol, a espiral descrita pelo navegador português confortava-se ainda com uma dimensão, ao mesmo tempo, terrena e escatológica, que correspondia aos propósitos históricos iniciais da viagem: o projecto imperial de D. Manuel $\mathrm{I}^{16}$, isto é, a conquista de Jerusalém, a confortar o rumo para oriente com esse sentido último de regresso ao lugar mais sagrado. Fossem quais fossem as condiçóes ideológicas que, na época de Camóes, justificavam uma renovada exaltação da luta contra o Isláo, o propósito de verdade era respeitado.

6. O problema tinha-o Dante resolvido à sua maneira, enciclopédica e medieval, mas a sua viagem não era deste mundo, apostava-se escatologicamente para além dos limiares da vida e da morte. Ou seja, de algum modo as características da realidade física eram indiferentes para a realização da sua jornada, preocupada com o status animarum post mortem. O mesmo problema veio Camôes a resolvê-lo, mas de modo diverso, fundindo conhecimento cósmico e alegoria no episódio terminal da Ilha dos Amores.

Na realidade, em fins do século XV, princípios do século XVI, em que todos os novos aspectos decorrentes dos descobrimentos marítimos não podiam ainda considerarse conceptualmente integrados pela mentalidade culta europeia, o expediente do Alighieri, com toda a sua geometria concêntrica de círculos infernais e esferas celestes, não era também adequado à nova matéria do real por todos os lados transbordante e portanto não transcendentalizável nem geometrizável. Agora, o vif du sujet e a sua própria inabarcabilidade, tâo versátil como sentida ainda em processo, impediriam decerto os esquemas requeridos para o modelo clássico. Só seria possível utilizar-se um modelo clássico se a realidade tivesse os seus parâmetros estabilizados e não tinha. Já se disse que os feitos guerreiros no Norte de África não chegariam para torná-lo possível. O poema Arcitinge, ${ }^{17}$ com que Cataldo Sículo cantou as façanhas de Arzila e de Tânger, demonstra-o exactamente, na sua exígua dimensão e no seu curto fôlego épico, sendo de notar que o texto se reportava a um dos poucos casos em que a figura real concretamente considerada podia ser tomada como protagonista directo dos acontecimentos.

7. Desde muito cedo, documentos régios, como a carta de privilégio passada pelo regente D. Pedro ao Infante D. Henrique $(1443)^{18}$ ou a carta que D. João II escreve em 1490 aos Reis Católicos ${ }^{19}$, ou ainda a carta que D. Manuel escreve a

16 "Tanto quanto sabemos, D. Manuel não acalentava sonhos de conquista militar da Ásia. Prendia-se à ideia de se tornar imperador, pretendendo muito provavelmente assumir o título depois de Jerusalém cair nas suas mãos (...) Isto significa que ele se sentia incumbido de uma missão universal para manter a justiça, a paz e a supremacia da fé cristã» (Luís Filipe Thomaz, De Ceuta a Timor, Lisboa, Difel, 1994, p. 196.)

${ }^{17}$ Incluído, com tradução portuguesa, por Américo da Costa Ramalho na sua antologia, Latim Renascentista em Portugal, Coimbra, Centro de Estudos Clássicos e Humanísticos, 1985, pp. 64-97.

18 Silva Marques, Descobrimentos Portugueses, I, p. 435.

19 As gavetas da Torre do Tombo, VII, p. 921. 
Maximiliano em $1499^{20}$, bulas papais, como a Romanus Pontifex $(1454)^{21}$ ou a Aeterni Regis Clementia (1481) 22 , oraçóes de obediência como as de D. Garcia de Meneses (1481), Vasco Fernandes de Lucena (1485) e D. Fernando de Almeida (1493) 23 e outras mais, a obra histórica, a epistolografia e os panegíricos de humanistas latinos, como Poggio Bracciolini, de que adiante se tratará, Mateus Pisano ${ }^{24}$, Cataldo ${ }^{25}$, Poliziano $^{26}$ e Giovanni Francesco Poggio ${ }^{27}$ - todos salientam, a seu modo, as campanhas marroquinas, a novidade consistente no desvendamento do mundo - «terras alias, mare aliud, alios mundos, aliaque postremo sidera (...) invenisti», escreve Poliziano a D. João II, numa fórmula que virá a ecoar ainda em Pedro Nunes -, a chegada a remotas partes completamente desconhecidas do saber dos antigos geógrafos, o preço humano e material e os grandes perigos envolvidos pelo empreendimento marítimo dos Portugueses, a importante determinação lusitana no combate ao Islão e na conversão das populações distantes à fé romana. A isto os humanistas acrescentam a nota de a realidade dos descobrimentos ter ultrapassado de largo quer as ficçôes, quer as façanhas verdadeiras da Antiguidade.

Mas nada de significativo acontece entretanto no plano da epopeia, quer no período que antecede a viagem de Vasco da Gama, quer no que imediatamente lhe sucede. Foi necessário aguardar ainda muitas décadas a vasta respiração épica de Camões. É possível que formas de expressão literária de outra ordem tenham distraído, por algum tempo, a atenção dessa necessidade épica. A poesia e o teatro de corte, a historiografia e a oratória, os relatos de viagens e a epistolografia, podem ter contribuído para, num momento em que o mundo se alterava dia a dia, não ter chegado a estabilizar-se a consciência dessa necessidade, por ser maior a avidez de informaçóes e não serem nenhuns ou quase nenhuns o recuo e a perspectiva indispensáveis. Juntamente com a nova imagem do orbe, o que parece ter sido notado primeiro foi a radical transformação da sociedade e a alteraçáo dos costumes, como o Cancioneiro de Resende, o teatro vicentino e, mais tarde, a Miscelânea de Garcia de Resende documentam.

${ }^{20}$ Cfr. José Manuel Garcia, "A carta de D. Manuel a Maximiliano sobre o descobrimento do caminho marítimo para a Índia”, Oceanos, n 16, Lisboa CNCDP, 1993, pp. 28-32. Inclui a versão portuguesa da carta, por Carlos Ascenso André.

21 Silva Marques, op. e vol. cit., p. 509.

22 Silva Marques, op. cit., III, p. 231.

${ }^{23}$ Cfr. Martim de Albuquerque (ed.), Orações de obediência dos reis de Portugal aos sumos pontifices, Lisboa, Inapa, 1988, e fascículos correspondentes; Luís de Matos, L'expansion portugaise dans la littérature latine de la Renaissance, Lisboa, Fundação Gulbenkian, 1991, pp. 157-185.

24 Cfr. Luís de Matos, op. cit., pp. 73-82.

25 Cfr. Américo da Costa Ramalho, Estudos sobre a época do renascimento, Coimbra, Instituto de Alta Cultura, 1969, pp. 31 e segs.; Estudos sobre o século XVI, Paris, Fundação Gulbenkian, 1980, pp. 29 e segs; "Cataldo", introdução a Cataldo Parísio Sículo, Epistolae et Orationes, Coimbra, Por ordem da Universidade, 1988, pp. 9-22. E Luís de Matos, op. cit., pp. 82-108.

${ }^{26}$ Cfr. as cartas de Policiano publicadas por Fidelino de Figueiredo, com tradução portuguesa, em $A$ épica portuguesa no século XVI, Lisboa, INCM, 1987, pp. 92-107.

${ }^{27}$ Fidelino de Figueiredo, op. cit., pp. 112-114, publica também uma parte do panegírico de Poggio. Cfr. a recensão de Rebelo Gonçalves à edição do Emmanuelis Portugalliae Regis Elogium, incluída em Obras Completas, Lisboa, Fundação Gulbenkian, 1995, pp. 541-547, e ainda Luís de Matos, op. cit., pp. 354-356. 
8. Será preciso esperar pela tentativa do jovem João de Barros, na Crónica do Imperador Clarimundo $(1520)^{28}$. Esta obra indicia a confirmação de alguns dos pontos que ficaram referidos. Nomeadamente torna-se evidente que uma narrativa épica ainda só era sustentável, para a mentalidade do tempo, muito mais pela utilização da matéria dos romances de cavalaria do que pela da matéria marítima. Neste sentido, escreve Daniel Madélenat que "l'épopée renaissante (...) unit la tradition médiévale au modèle homérique» ${ }^{29}$. Cabe todavia a João de Barros o mérito de ter posto precursoramente a história de Portugal em oitavas de arte maior ${ }^{30}$, um tanto ou quanto desajeitadas é certo, entremeadas de passagens em prosa, seguindo modelos rimáticos e prosódicos muito diferentes dos da oitava italiana e do decassílabo heróico e mais limitativos para a progressão narrativa, até pela simetria interna e fechada de cada estrofe ${ }^{31}$. O que só evidencia que a língua literária ainda carecia da importação dos modelos italianos que veio a ter lugar a partir de Sá de Miranda, na segunda metade da década de 1520 1530, e que Barros estava reduzido a lançar mão de esquemas que o Condestável D. Pedro $^{32}$, Juan de Mena no Laberinto de Fortuna, Gil Vicente ${ }^{33}$, Luís Anriques ${ }^{34}$ e outros tinham utilizado, também se inspirando talvez nas crónicas rimadas castelhanas ${ }^{35}$. O importante é que o futuro cronista das Décadas da Ásia perspectivou a história de Portugal solidarizando-a, como na oração do Dr. Vasco Fernandes de Lucena já acontecia e como n'Os Lusíadas veio a acontecer esplendorosamente, com os mais recentes eventos da expansão marítima e com um percurso geográfico repartido pelo mundo. Mas, não obstante a importância dos feitos que abreviadamente refere - e ele exprime, por exemplo, uma perfeita consciência da importância da viagem de Bartolomeu Dias: "E aquele grá Cabo de Boa Esperança / Que tanta de terra esconde ao Mundo»-, João de Barros não consegue mais do que fazer encabeçar na figura do rei os grandes feitos cantados. É sintomático que, nessas oitavas da profecia de Fanimor, se consiga cantar a expansão portuguesa projectada no planeta, sem se fazer referência a um único navegador!

Curto como era, este fôlego não deixou com certeza de contribuir também para a fixação de um núcleo de ideias ligadas à necessidade de elevada celebração literária dos feitos marítimos dos Portugueses. Já muito antes da viagem a Calecute elas estavam no ar. Basta percorrer o livro monumental de Luís de Matos, L'expansion portugaise dans la littérature latine de la Renaissance, para verificá-lo. Mas, quaisquer que fossem as

28 João de Barros, Clarimundo, Lisboa, Sá da Costa, 1953.

29 Daniel Madélénat, L'épopée, Paris, PUF, 1986, p. 214.

${ }^{30}$ Id., ibid., III, pp. 92-111.

${ }^{31}$ Cfr. Maria Rosa Lida de Malkiel, Juan de Mena poeta del prerrenacimiento español, México, El Colegio de Mexico, 1984, p. 197.

${ }^{32} \mathrm{Na}$ conclusão da "Satira de infelice e felice vida" (Condestável D. Pedro, Obras Completas, Lisboa, Fundação Gulbenkian, 1975, p. 169).

33 Por exemplo, no Auto de S. Martinho, ou no final do Auto da Fama.

${ }^{34} \mathrm{Na}$ "Lamentaçam aa morte d'el-rei Dom Joham, que santa groria haja" (Cancioneiro Geral, no 366).

35 Por exemplo, a Consolatoria de Castilla, de Juan Barba, em que, de um modo geral, a estrofe obedece também ao esquema rimático abbaacca e tem uma métrica semelhante. Cfr. Pedro M. Cátedra, $L a$ historiografía en verso en la época de los Reyes Católicos, Salamanca, Universidade, 1989. 
intençôes e os projectos, que evidenciam uma noção muito clara do grau de novidade e progresso devido a tais empreendimentos, a verdade é que náo foram polarizados num protagonista, salvo no próprio rei, ao contrário do que, mais tarde, veio a fazer Camóes. Antes do Gama, não havia propriamente um herói disponível. O Gama mal se ajustava ao figurino, como protagonista susceptível de ser configurado como herói épico perante as convençóes de um programa correspondente. Segundo Lesky, que se reporta a estudos comparativos conhecidos, a poesia heróica teve «sempre a pretensáo de narrar factos verdadeiros» ${ }^{36}$ e esse era de novo o caso. Mas agora o verdadeiro, o extraordinário verdadeiro, parecia convir mal a tais propósitos, por as façanhas individuais corresponderem menos à tipologia de comportamentos prevista pelo receituário...

9. Diferentemente se passam as coisas, na altura em que Camóes escreve. Fora publicada a Ars Poetica de Girolamo Vida (1527) com a sua forte ênfase na matriz virgiliana, embora não possa ter-se por seguro que Camóes conhecesse directamente esse tratado, "consagração inequivoca do virgilianismo florescente na primeira metade do século $X V I_{\gg}{ }^{37}$. Já estavam então disponíveis em vulgar algumas traduçóes integrais ou parciais das epopeias clássicas em Castelhano, uma delas da Eneida, por Gregorio Hernández de Velasco, que saiu em 1555 e foi várias vezes reeditada, "em oitavas reais para os discursos e em verso branco para a narração" ${ }^{38}$, o que pode ter relevância para a questão camoniana. Na primeira metade do século XVI, em Portugal, ocorriam importantes alteraçóes nos programas de Humanidades, reconduzindo à matriz clássica, entre outras disciplinas, a Gramática, a Retórica e a Poética ${ }^{39}$, o que não podia deixar de criar um ambiente propício à difusão da obra virgiliana. E já se tinha feito sentir insistentemente entre nós a necessidade do canto épico, talvez até porque a decadência do império português tinha entretanto começado e convinha encontrar para ela um mecanismo de compensação ideológica e emocional. Por outro lado, já está perfeitamente institucionalizado um sistema de representação do poder real na Índia, exercido por vice-reis e por governadores. Vasco da Gama, ele próprio, havia sido nomeado vice-rei da terceira vez que se tinha deslocado ao Oriente (1524). Cantá-lo tornava-se por isso mais fácil, em tal perspectiva, uma vez que a sua figura funcionava como a própria emanação da pessoa do rei que era, em última análise, o sujeito central da História cantada e o destinatário do canto, do mesmo rei que lhe dera o regimento para a expedição ("porque cumprisse / O regimento em tudo obedecido» - Lus. II, 103). Esses eram sinais de legitimação de origem real, caracterizadores do herói ${ }^{40}$. Simbolicamente os seus feitos acabariam por ser imputados à glória do monarca que os mandara praticar e de D. Sebastiâo, que dele descendia e que, no poema, também era suposto presenciá-los e assumi-los simbolicamente.

36 Albin Lesky, História da Literatura Grega, Lisboa, Fundação Gulbenkian, 1995, p. 32.

37 Cfr. Arnaldo M. Espírito Santo, "Introduçâo" a Arte Poética de Marco Girolamo Vida, p. 132 e ainda pp. 59, 60, 64, 66, 67.

38 Maria Rosa Lida de Malkiel, La tradición clásica en España, Barcelona, Ariel, 1975, pp. 369-370; cfr. Daniel Madélenat, op. cit., p. 218.

${ }^{39}$ Aníbal Pinto de Castro, Retórica e teorização literária em Portugal / Do Humanismo ao Neoclassicismo, Coimbra, Centro de Estudos Românicos, 1973, pp. 17-32.

${ }^{40}$ Cfr. Daniel Madélénat, op. cit., p. 54. 
É, além disso, natural que novas formas de individualismo, conexas com a competição aristocrática e a profusão de sucessos militares no Oriente, contribuíssem para gerar outras condiçóes propícias para isso. Tratava-se de múltiplos sucessos de que havia notícia, ocorridos num espaço que se tornara conhecido entretanto. Havia que identificar um herói "vestibular" de cuja acção fundadora decorresse tudo isso. E tudo isso vinha somar-se à história heróica da nação, adensando-a, quando já se dispunha de uma informação muito mais vasta sobre o mundo asiático, o recorte dos continentes e a realidade física do planeta, a cuja configuração esférica precisa Fernão de Magalhães, por sinal o último caso de expedição marítima referido n'Os Lusíadas (X, 140), trouxera a prova concreta. A realidade do espaço era concebida de novo como abarcável no seu conjunto.

10. Para chegar a um molde épico digno da viagem, Camóes não fez apenas a experiência pessoal dela confrontada com o ensinamento dos clássicos, a recepção deles em vulgar e as possibilidades da sua própria perícia versificatória; teve o engenho de encontrar uma analogia que lhe permitiu configurar devidamente o protagonista e estruturar a sua viagem para o efeito. Recorreu à comparaçâo com Eneias. É muito significativo que esta seja a primeira referência que n'Os Lusíadas é feita a Vasco da Gama (I, XII):

"Dou-vos também aquele ilustre Gama Que para si de Eneias toma a fama."

Faria e Sousa viu muito bem a importância desse paralelo no seu juicio del poema:

"Sale Eneas de Troya, llega a Cartago, adóde la Reyna Dido le recibe, i hospeda festiva i pomposamente; con que fenece el libro I. Sale Vasco da Gama de Lisboa, llega a Melinde, cuyo Rey pomposa i festivamente le hospeda i recibe: advirtiendo, que para que a Eneas con Reyna enamorada del, no dexasse de corresponder el Gama, allà al fin del c. 9. le desposa con Tetis, que al principio del 10. le banquetea como Dido a Eneas. Adelante. Pide Dido a Eneas al fin del c. I. que le cuente su navegacion, i las cosas de su patria, i motivos de dexarla, i venir tan lexos (...) Pide el Rey de Melinde al Gama lo mismo al fin del c. 2. i él le satisfaze en los tres siguientes, 3.4.5. Parte Eneas de Cartago, i llega a aquella parte de Italia, en que traia puesta la proa, i habla por medio de sus Embaxadores con Latino, i despues de varias dificultades peligrosas, consigue el fin de su viaje. Parte el Gama de Melinde para el Imperio del Malabar, que era el termino de su deseo, llega a Calecut, propone su embaxada al Rey, i despues de semejantes peligros, conseguido su intento buelve a la patria." ${ }^{41}$

Em termos estritamente renascentistas, e na ausência de grandes feitos guerreiros individuais de força, coragem e defesa da honra, que pudessem ser cantados heroicamente, o processo épico náo seria concebível no caso concreto da viagem de

\footnotetext{
${ }^{41}$ Manuel de Faria e Sousa, Lusiadas comentadas, I, col. 72-73. Cfr. Helder Godinho, "Para uma mitocrítica de Os Lusíadas", in A viagem de "Os Lusíadas": símbolo e mito, pp. 44-45.
} 
Vasco da Gama. Estou em crer que só o foi porque, entretanto, um quadro cultural já maneirista permitia tais distorçôes, translaçóes e desvios à regra consagrada, até no propósito de utilização da "tuba canora e belicosa» ao contrário do preceituado por Vida: «aquele delira com o ruido, esforça-se por igualar com a voz os sons das trombetas e troveja sem regra em todos os versos» ${ }^{42}$. Talvez seja esta atitude transgressiva dos modelos fixados o verdadeiro alvo dos epigramas desfechados pelo estro pouco "modernista" de Pedro de Andrade Caminha, quer quando verbera a "fúria de um poeta", quer quando escreve:

"A teu sabor escreves o que escreves,

A Leis d'outros Poetas não te obrigas;

Tambem tu és poeta, e nom te deves

Atar a Leis da Poezia antigas;

Faze Leis, e desfaze, como fazes,

Rite dos outros se te satisfazes." 43

11. Ora, não obstante todo o tempo decorrido e a enorme acumulação de conhecimentos que desde então tivera lugar, não obstante a evolução da língua e dos conceitos da poética, foram as viagens da primeira metade do século XV que suscitaram o desenvolvimento, fora de Portugal, do programa conceptual que veio ainda a servir à proposição de Os Lusiadas, mais de 120 anos depois.

Ainda estava muito longe de eclodir qualquer sentido da necessidade de uma epopeia que cantasse os feitos do Portugueses, antes ou depois da viagem de Vasco da Gama, quando, na consciência europeia culturalmente atenta, surge uma clara concepção das características inovadoras das viagens portuguesas, em ruptura com o saber relativo ao mundo até então conhecido, e também a ideia de que elas superavam os feitos dos grandes nomes da Antiguidade.

Vasco da Gama torna-se deste modo uma figura que é iluminada n'Os Lusiadas por uma luz que vem de Poggio Bracciolini e pela carta que ele escreveu ao Infante D. Henrique cerca de 1448/49 ${ }^{44}$. Este célebre humanista florentino, recuperador de livros e manuscritos clássicos ${ }^{45}$ e membro da cúria, autor material das minutas de bulas papais de interesse para a coroa lusitana, amigo de Vasco Fernandes de Lucena e de outros letrados portugueses, era pai do Giovanni Francesco Poggio autor do Elogium do rei $\mathrm{D}$. Manuel que já foi referido. $\mathrm{Na}$ sua carta encontram-se explicitamente formulados, é de crer que pela primeira vez, os pontos essenciais abordados por Camóes na proposição de Os Lusíadas, que assim não faz mais que retomar tópicos que eram já muito antigos para o seu tempo e que tinham sido percorridos, quase ipsis verbis, por quantos vieram depois de Bracciolini.

\footnotetext{
42 Arte Poética, I, vv. 181-182, p. 155.

43 Poezias de Pedro de Andrade Caminha, Lisboa, Academia das Ciências, 1791, p. 352.

${ }^{44}$ José Manuel Garcia, "O elogio do Infante D. Henrique pelo humanista Poggio Bracciolini”, Oceanos, no 17, Lisboa, CNCDP, 1994, pp. 12-14. Inclui a carta de Poggio, traduzida por Carlos Ascenso André.

45 Cfr. Phyllis Walter Goodhart Gordan, Two Renaissance Book Hunters, New York, Columbia University Press, 1991.
} 
Resumindo muito, Poggio refere as navegaçōes por «mares ignorados, regióes nunca antes visitadas, naçóes desconhecidas e selvagens, postas nos mais remotos confins, fora do alcance do ano e do sol, para onde ninguém antes desvendara o caminho", compara os feitos do príncipe português com os de Alexandre e de César, - «a tua coragem (...) estendeu-se àquelas regióes do mundo que ninguém, antes de ti, se lê ter atingido»; "a tua armada (...) contornou aquelas partes que nem eram conhecidas nem de fácil acesso e que, devido ao pavor do mar e das gentes bárbaras, eram olhadas com receio pelos navegantes» -, louva o combate contra os infiéis, e exorta o Infante a continuar a sua obra para exceder os restantes príncipes "pela fama e pela glória dos feitos alcançados».

Giovanni Francesco Poggio, o filho do correspondente do infante, como se disse, virá também a escrever sobre D. Manuel, em começos do século XVI. Luís de Matos data este texto de 1514, com base em que a chegada à Taprobana (Ceilão) é o único facto histórico referido ${ }^{46}$. Mas o argumento poderá não colher inteiramente. $\mathrm{Na}$ carta de D. Manuel a Maximiliano (1499) já se fala na exploração da Taprobana pelos Portugueses... O que interessa aqui, todavia, é o facto de poder explicar-se, por uma cadeia que vai de pai a filho e alastra noutras direcçóes, a génese dos tópicos que os humanistas vieram a utilizar com tanta frequência e que passaram depois às letras portuguesas.

Interessa também observar que, nesses anos de 1448/49, os Portugueses ainda tinham avançado relativamente pouco para além do Cabo Bojador: haviam chegado à costa da Guiné em 1445 e nem sequer estavam descobertas as ilhas mais ocidentais dos Açores (1452). A grande novidade tinha, afinal, um alcance ainda muito curto face às muito maiores e muito mais importantes evidências relativas à imagem do mundo que as viagens seguintes tornariam conhecida. E todavia, para Poggio, que não podia deixar de ter boa informação sobre o oriente, dado o seu contacto com Niccolò de Conti ${ }^{47}$, tais factos, que apenas tinham tornado conhecido "um pouco mais" do recorte da costa do noroeste africano, eram já verdadeiramente revolucionários!

12. Assim, a grande distância ainda do feito de Vasco da Gama se encontrava completamente elaborado um conjunto de elementos que Camóes recuperou para a proposição de Os Lusíadas. Identicamente, muito depois desse feito, no momento em que Camôes o celebra, o conjunto de informaçôes entretanto disponíveis sobre a face da Terra e sobre os mares surge convocado na celebraçáo pelo expediente da contemplação da máquina do mundo.

Nessa determinação global da realidade física da Terra implicava-se, de resto, uma distinção importante. O mundo em que Camóes inscreve as realizaçóes dos Portugueses, e que Tethys aponta minuciosamente a Vasco da Gama, corresponde com exactidão ao delimitado pelo Tratado de Tordesilhas em favor de D. João II. Vai de Santa Cruz às Molucas. $\mathrm{O}$ resto é expedido com algumas generalidades, ou como enunciação de pontos de referência geográfica (os pólos, o Austro, o Arcturo), ou como rapidíssima menção da zona que a Espanha passara a dominar nas Américas (Lus. X, 139-141). Isto é, Vasco da Gama, novo Eneias, abre a via a um império que abarca exactamente

\footnotetext{
46 Luís de Matos, op. cit., p. 354.

${ }^{47}$ Dedicar-lhe-á o quarto livro do De varietate fortunae. Niccolò de Conti passara vinte e cinco anos na Índia e em Java (Ph. Gordan, op. cit., p. 15).
} 
metade da Terra. Entretanto, a presença portuguesa no Oriente tinha-se tornado uma realidade multifacetada e efervescente. Já não era apenas a viagem inicial, eram todas as consequências que estavam à vista de uma era nova, aberta pelo Gama, que o tempo da história tornava solidária com a história de Portugal anterior a 1498, num espaço concebido à escala do mundo de que ficara a caber-nos todo um hemisfério por expansão heróica do pequeno rectângulo do ocidente ibérico. Definidos esse império e os seus limites, já se torna possível cantá-lo, inscrever a acção dos protagonistas nesse espaço, fazer ondular os tempos da história, do mito e da profecia na espiral dessa progressáo.

13. Epifânio da Silva Dias colacionou minuciosamente os passos de Barros e de Castanheda que são provavelmente a fonte da maior parte das estrofes 93 a 141 do Canto X. Sobretudo no tocante a Barros, ocorre em Camóes uma coordenação de textos que não se encontram todos no mesmo livro da Década Primeira da Ásia (I, 9, 1). A sua descrição é integrada com elementos colhidos na Década terceira, nomeadamente para os casos das estâncias 112, 126, 132, 133, 135, 137 e, nalguns casos, em Castanheda. O olhar de Camóes percorre a costa oriental de África (93-96), passando à entrada do Mar Roxo e à Arábia (97-100) e desta à Pérsia (101-105) e à Índia (106-121), depois segue da Índia ao reino do Pegu (122), Sião, a Indochina, Malaca e o Cambodja (123125), China e Japão (129-131), ruma em direcção à Insulíndia (132-134), e volta em seguida "para trás", de modo a focar também as ilhas de Sumatra (135), Ceilão (136), Socotorá e Madagáscar (137), antes de referir, em brevíssimas passagens, a América espanhola (139), o Brasil (140) e o estreito de Magalhães (141). Dir-se-ia que esse recorte se baseia numa expressão cartográfica, aliás inculcada por X, 120:

"Mas passo esta matéria perigosa,

E tornemos à costa debuxada..."

É muito natural que, para tal debuxo, Camôes não tenha recorrido apenas às fontes referidas, reportando-se também a peças cartográficas para encontrar um fio condutor visual que ordenasse a matéria do percurso que propóe.

Talvez ele tenha tido debaixo dos olhos algumas folhas desenhadas por Fernão Vaz Dourado ${ }^{48}$. Este cartógrafo, que era da sua idade, nascera, vivia e exercia o seu ofício na Índia, certamente em contacto com círculos cultivados de Goa, havendo portanto muitas probabilidades de Camóes o ter conhecido pessoalmente.

Era, de resto, o próprio Barros quem dava tal conselho de recurso à cartografia, no texto da Década Primeira da Ásia que Camóes estava a utilizar:

"E por toda esta distância que há do cabo Segógora té Chatigam, é mais pera pintura que escritura por ser toda terra cortada em ilhas e baixios que fazem as bocas do Ganges com a cópia das suas águas: não nomeamos as cidades e povoações que estão por estas ilhas, os curiosos da situação delas em as tábuas da nossa geografia a podem ver" ${ }^{49}$,

${ }^{48}$ Cfr. Luís de Albuquerque, "Introduçáo" ao Atlas de Fernão Vaz Dourado, Lisboa, CNCDP, 1991.

49 João de Barros, Ásia, primeira Decada, I, 9, i. (Coimbra, Imprensa da Universidade, 1932, pp. 344-345). 
o que podia abonar-se também com uma recomendação de Girolamo Vida, se acaso Camóes chegou a lê-lo, e que corresponderia a traduzir o seu próprio percurso pessoal:

"É útil que o aluno tenha observado os vários costumes dos povos e a geografia dos lugares, e que, ou em pessoa, por terra e por mar, tenha visitado muitas cidades ou delas tenha notícia pela narração de outros e conheça o mapa do mundo" 50 .

14. Dessa possível utilização da cartografia na poética, creio bastarem dois exemplos. Em Os Lusíadas X, 125, Camóes escreve:

"Mas na ponta da terra Singapura

Verás, onde o caminho às naus se estreita;

Daqui tornando a costa à Cinosura

Se encurva, e para a Aurora se endireita.

Vês Pam, Patane, reinos, e a longura

de Sião que estes e outros mais sujeita.

Olha o rio Menão que se derrama

Do grande lago que Chiamai se chama."

Nas referências que Barros faz, no mesmo lugar da Primeira Década ${ }^{51}$, ao cabo de Singapura e restantes topónimos da estrofe, não vem referido aquele "caminho a estreitar-se às naus", nem aquela configuração da costa, a curvar para norte e a voltar-se para nascente, junto ao golfo de Sião. Mas tudo isso é visível, sobretudo aquele "encurvar-se", nas cartas constantes dos fólios 28-29 e 30-31 do Atlas de Fernão Vaz Dourado, da Biblioteca Nacional, que é de 1568 e cuja feitura supóe, evidentemente, muitos trabalhos cartográficos parcelares anteriores a ele.

No segundo caso, em Os Lusíadas, X, 129, lê-se: "E de Ainão vê a incógnita enseada». Barros refere a ilha de Ainão no lugar correspondente, mas não faz nenhuma referência a qualquer enseada ${ }^{52}$. Limita-se a apontar uma mudança de rumo da costa, para noroeste, "em que acaba a octava parte e começa a nova que dissémos ná ser ainda per os nossos navegada». Mas, no mesmo Atlas de Fernão Vaz Dourado da Biblioteca Nacional, a ilha de Ainão inscreve-se no espaço correspondente a uma vasta enseada. Há aqui dois tempos históricos enlaçados: incógnita para Vasco da Gama, a enseada já náo o era no tempo em que Camóes escrevia.

15. Fiquemos por aqui. Do tempo de Poggio Bracciolini ao tempo de Camóes, se foi assim organizando, entre a tradição sedimentada pela retórica dos humanistas, a partir de 1448/49, e a novidade geográfica espelhada com precisão minuciosa pela arte dos cosmógrafos contemporâneos do poeta, o cenário espacialmente adequado para a figura, tornada épica, de Vasco da Gama.

\footnotetext{
50 Arte Poética, I, vv. 391-394 (p. 173).

51 Id., ibid., p. 346.

52 Id., ibid., p. 347.
} 